Article

\title{
Collaborative Modeling to Assess Drought Resiliency of Snow-Fed River Dependent Communities in the Western United States: A Case Study in the Truckee-Carson River System
}

\author{
Loretta Singletary ${ }^{1, *}$ and Kelley Sterle ${ }^{2}$ \\ 1 Department of Economics and Cooperative Extension, University of Nevada, Reno, NV 89557, USA \\ 2 Graduate Program of Hydrologic Sciences, University of Nevada, Reno, NV 89557, USA; ksterle@unr.edu \\ * Correspondence: singletaryl@unr.edu; Tel.: +1-775-682-9138
}

Academic Editors: Karina Schoengold, Kristiana Hansen and Ginger Paige

Received: 20 October 2016; Accepted: 3 February 2017; Published: 9 February 2017

\begin{abstract}
Assessing the drought resilience of snow-fed river dependent communities in the arid Western United States has taken on critical importance in response to changing climatic conditions. The process of assessing drought resiliency involves understanding the extent to which snow-fed dependent communities can absorb the effects of uncertain and variable water supplies while acknowledging and encouraging their capacity for adaptation. Participatory research approaches are particularly well suited to assess resiliency in this context because they rely upon local water managers' knowledge and perspectives. The research presented here provides measured insight into local water managers' perceptions of drought resiliency in the Truckee-Carson River System in northwestern Nevada. These findings are reported in the context of the collaborative modeling research design developed for this case study. The objectives of this study are: (1) to define resiliency and present a rationale for a participatory approach to assess drought resiliency in snow-fed arid river basins in the Western United States; (2) to outline collaborative modeling as a participatory research design developed for the Truckee-Carson River System case study area; (3) to describe the development and implementation of a resiliency assessment undertaken to implement this research design; (4) to highlight selected results of the assessment, summarizing interviews with 66 water managers in the case study area; (5) to discuss the use of assessment findings to inform collaborative modeling toward adaptation strategies; and (6) to review lessons learned to date from the collaborative modeling case study and note opportunities for further exploration. According to water managers surveyed, climate change is very important and is mobilizing adaptation strategies that include improvements in communication and coordination with other water managers, monitoring and data collection, and planning. The majority of water managers indicate that future adaptation requires modifying institutionalized water management regimes to allow for temporary water leasing programs, water right stacking on the most productive agricultural lands while fallowing marginal lands, incentivizing water conservation, reducing or eliminating residential landscaping, and recruiting less water intensive industry to the region.
\end{abstract}

Keywords: collaborative modeling; drought; resiliency; adaptation

\section{Introduction}

Assessing the drought resilience of snow-fed river dependent communities has taken on critical importance in response to changing climatic conditions and uncertainty. Climate change is impacting precipitation patterns challenging the resiliency of snow-fed river basins in the arid Western United States. Evidence to date indicates that increases in temperature and precipitation impact 
mountain snowpack on a global scale, and the extent of impact depends upon elevation, latitude, and location [1]. Significant changes have been observed in the mean flows of many river basins [2] with observed earlier peak flow trends increasing since the mid-20th century. Shifts in the timing of snowmelt have reduced water supplies particularly during dry, warm periods [3]. Global mean surface temperatures have warmed in recent decades, and the warming trend is expected to continue into the future [4].

The Intergovernmental Panel on Climate Change suggests that the number of areas affected by drought and earlier snowmelt will likely increase, adversely affecting water supplies available for municipal, industrial, and recreational use, wildlife habitat, as well as energy and food production $[5,6]$. Because of the broad range of ecosystem services provided, in addition to other social, economic, and environmental factors, the resiliency of snow-fed river dependent communities to adapt to climate change may differ based upon location on the system and timing of water demand.

An assessment of drought resilience involves understanding the factors unique to snow-fed dependent communities that challenge community sustainability. Resiliency in this context is defined as the capacity of natural (river) and human (community) systems to absorb climatic disturbance while retaining their essential purpose and function [7]. Resilience does not assume a return to an original state [8], but suggests that weaker system components may fail under climatic stress while other components continue to function, allowing key components to cooperatively reorganize as necessary to survive [9-11].

Resilience is influenced by economic, demographic, cultural, historical, institutional, and environmentalt factors. This is evident in highly regulated river systems. Snow-fed river systems in the arid Western United States, for example, typically depend upon an extensive set of institutional arrangements to regulate water use to surrounding communities. This includes prior appropriation doctrine or as well as litigated outcomes and negotiated settlement agreements in response to emergent and contentious issues involving competing water demand.

Reduced water supplies for prolonged periods may threaten multiple ecosystem services that rivers provide, including adequate water quantity and quality to sustain human life, wildlife habitat, ecological health, economic development, and food security. Variable water supplies as a result of drought may increase water conflict among competing water users [12]. Cooperation among stakeholder groups upstream to reorganize in order to survive drought conditions, for example, may positively or negatively impact stakeholder groups downstream [13].

Alternatively, these same water supply reductions may result in unprecedented opportunities for cooperation and collaboration [14]. Particularly in shared river basins, formal institutional arrangements and management regimes are instrumental in managing disputes under variable water supply conditions $[15,16]$.

Assessing resilience involves understanding local knowledge of river system function, community interdependency upon the water resource, and the community capacity to adapt to drought [17]. Local stakeholders, including water managers and individual water right holders, are instrumental in influencing river system and community sustainability [18,19].

The objectives of this study are: (1) to define resiliency and present a rationale for a participatory approach to assess drought resiliency in snow-fed arid river basins in the Western United States; (2) to outline collaborative modeling as a participatory research design developed for the Truckee-Carson River System case study area; (3) to describe the development and implementation of a resiliency assessment undertaken to implement this research design; (4) to highlight selected results of the assessment, summarizing interviews with 66 water managers in the case study area; (5) to discuss the use of assessment findings to inform collaborative modeling toward adaptation strategies; and (6) to review lessons learned to date from the collaborative modeling case study and note opportunities for further exploration. 


\section{Collaboratively Assessing Resiliency}

\subsection{Collaborative Modeling as a Participatory Approach}

A participatory research design acknowledges that local stakeholders have an interdependent and vested interest in assessing their resilience to climate induced water supply variability. This research design engages scientists and stakeholders in effective dialogue with one another to produce information useful for strengthening the capacity of communities to seek sustainable solutions while advancing science research $[20,21]$.

Increasingly, theoretically grounded science research surrounding complex problems stemming from climate uncertainty is adopting such participatory approaches [11,22] including group model building, participatory modeling, multi-criteria/multi-decision-making, and collaborative modeling [23]. These approaches are characterized by thoughtfully planned and implemented group procedure, which includes facilitated discussion, deliberation, and problem solving [21,24]. Effective participatory research approaches prioritize mutually beneficial knowledge exchange between scientists and local stakeholders. This exchange results in social learning [25]. That is, individuals, whether they are scientists or stakeholders, do not innovate in isolation but as a result of interaction and communication with one another [26,27]. In the context of adapting to climate uncertainty both scientists and local water managers have high stakes in participatory research outcomes.

The definition of resilience adopted here suggests that for adaptation to occur through social learning, climate science research must produce information relevant and useful to local water managers and other decision-makers. For instance, the effect of increasing temperature is meaningful to water managers in terms of how it interacts with their local demographic, economic, or environmental realities $[17,28]$. Coincidently, scientists strive to examine available and preferred decisions under climate-induced stress, which can aid in resiliency planning and adaptation for example, while also forwarding research.

Collaborative modeling provides one example of participatory research to assess resiliency. It requires that scientists seek and value local knowledge as part of their scientific inquiry and that water managers provide local knowledge and input willingly to ensure that the resulting research information is useful. As such, it strives to establish constructive dialogue between scientists and local water managers.

\subsection{Truckee-Carson River System: A Collaborative Modeling Case Study}

In highly regulated snow-fed arid land river systems, such as the Truckee-Carson River System, institutional arrangements as well as organizational and individual decisions to address water variability play a critical role in system wide water resource sustainability (Figure 1). The high desert communities of northwestern Nevada rely upon winter snowpack and spring snowmelt as their primary source of water, making them susceptible to climate-induced disturbances [29].

The Truckee River Basin encompasses approximately $7925 \mathrm{~km}^{2}$. While $75 \%$ of the basin lies in northwestern Nevada, a majority of the water storage exists in the snowpack, streams, and reservoirs of eastern California's Sierra Nevada. The 1971 California-Nevada Interstate Compact allocated 90\% of the Truckee River's waters to Nevada.

The nation's first United States Bureau of Reclamation project, the Newlands Project, was constructed on the Truckee River. Completed in 1905, Derby Dam diverted Truckee River flows away from the river and Pyramid Lake via the Truckee Canal to join Carson River flows at Lahontan Reservoir, providing agricultural irrigation supplies to the Newlands Project. Extensive periods of litigation and negotiation have produced the arrangements that govern the river system today. Current issues include: increased municipal demand, minimum flows required to maintain Pyramid Lake fisheries, periods of low precipitation and river flows during droughts, flood management during extreme high flow events, use of water rights appropriated through reservoir releases during flood periods, and decreasing water quality [30,31]. 


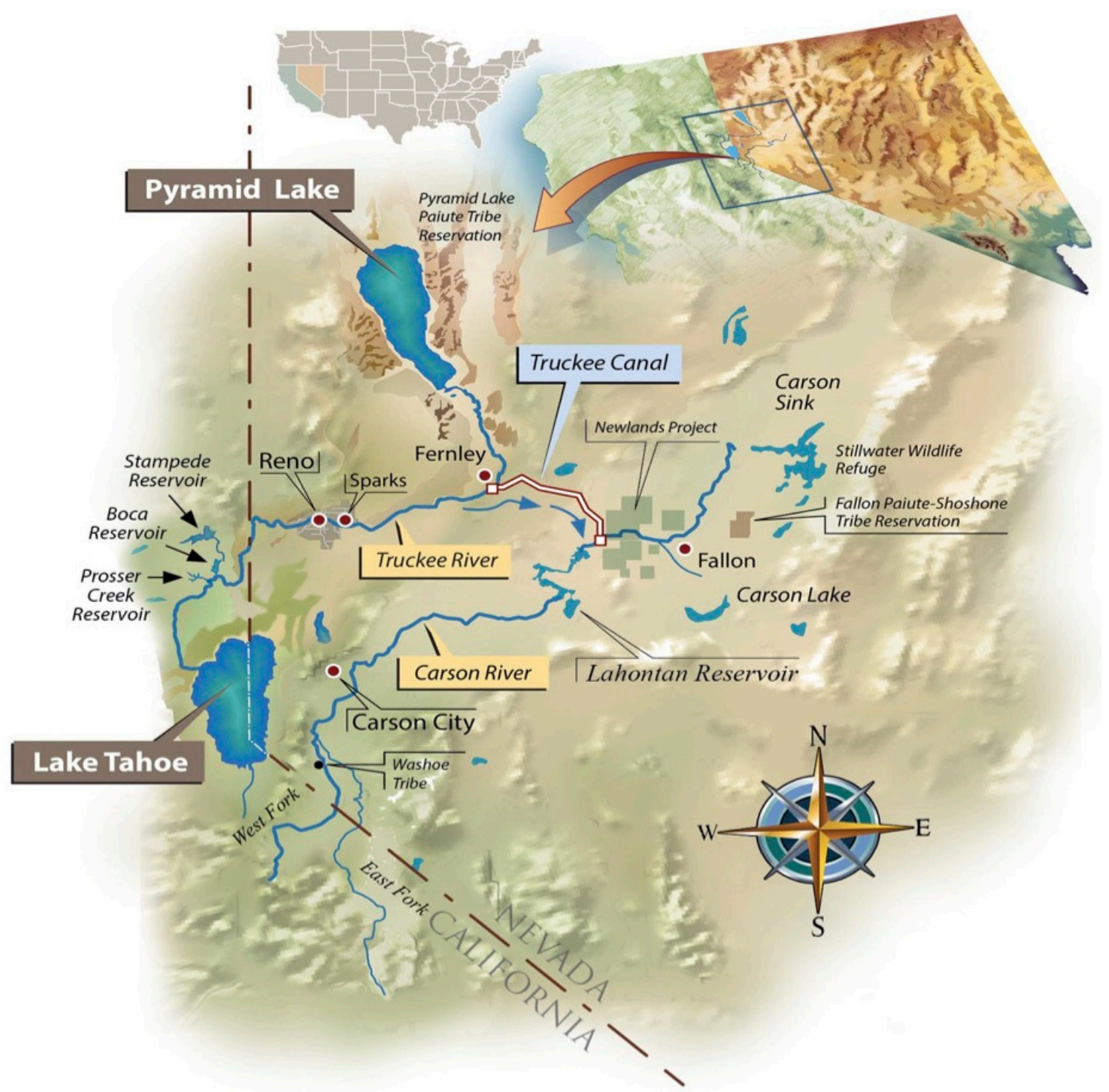

Figure 1. Truckee-Carson River System.

The Carson River also originates in the eastern Sierra Nevada as snowpack. Within the $10,270 \mathrm{~m}^{2}$ area basin, nearly $15 \%$ of the total area is located in eastern California, while $85 \%$ is located in northwestern Nevada [31]. As with the Truckee River, a federal compact regulates interstate resource sharing. The Carson River involves the oldest litigation over water right adjudication in the United States, with one case alone spanning 55 years, and resolved through the Alpine Decree (1980), which today is the primary governance regime over that river's water rights allocation [31]. Since 1915, its waters have been captured and stored in Lahontan Reservoir to supply additional agricultural irrigation water for the Newlands Project downstream and surrounding rural communities [30].

Within a relatively small geographic area, the Truckee-Carson River System encompasses the major elements of water supply and demand issues facing snowpack dependent communities throughout the Western United States. These include increased municipal water demand to support economic development and population growth, water historically appropriated for agricultural irrigation, and increasing needs to protect stressed ecological systems [30]. The Truckee-Carson River System supplies water to a number of municipalities, sovereign tribal lands, one of the largest industrial parks in the United States, federal wildlife refuges, and a rare natural desert terminus lake located on the 
Pyramid Lake Paiute Tribe's Reservation. Pyramid Lake is home to the endangered Cui-ui fish and the threatened Lahontan cutthroat trout [32].

The river system's water supplies are critically dependent on the timing, form, and amount of precipitation in the Sierra Nevada. As with many rivers in the American West, water use is highly regulated through federal, tribal, state, and local water sharing agreements. These institutionalized water management arrangements and regimes were built on historic prior appropriation doctrine developed during late 19th century. Due to historical over-adjudication of water rights, western water supplies are currently over-subscribed. Most analysts predict water management in the Western United States will need to undergo extensive changes to adapt to climatic change and population increases anticipated for the region [33-35].

\subsection{Collaborative Modeling to Assess Resiliency in the Case Study Area}

The collaborative modeling research design developed for the Truckee-Carson River System case study area strategically links scientists with local water managers through a set of applied research methods integrated with Extension outreach. As such, it features a suite of standard primary data collection methods that draw upon local knowledge to inform and, through social learning, enlighten theoretically grounded science research. To provide an overview of the case study collaborative modeling research design, Table 1 lists each primary data collection method, its intended purpose, the substantive issue and/or research question the method seeks to address, and procedures necessary to implement the method. Extension outreach is included and its role explained in supporting iterative social learning involving scientists and stakeholders.

Results from a stakeholder analysis [36], conducted prior to initiating the case study, indicated a high interest among local water managers to participate in research localized to the Truckee-Carson River System aimed at seeking solutions to water shortages imposed by the current drought (2012-2015) [37]. The analysis identified 12 water management organizations that represent diverse water use interests from the headwaters of the river system to the Truckee River desert terminus (Pyramid) lake and the river system terminus (Newlands Project) below the Truckee Canal and Lahontan Reservoir. Figure 2 illustrates these interests, identified here as the Stakeholder Affiliate Group, and their respective water management areas distributed across the river system. These key water management stakeholder communities represent agricultural, municipal and industrial, planning, environmental, and regulatory and information roles, engage with scientists to iteratively assess drought resiliency and adaptation strategies.

A key goal of this collaborative modeling research design is to engage local water managers directly in the process of identifying plausible climate scenarios in the case study area, which are then used to simulate hydrologic and operational outcomes through a suite of models that geographically span the river system. (The hydrologic models include the USGS MODFLOW, PRMS, and GSFLOW models. The operations models include the Truckee RiverWare model, developed by the Bureau of Reclamation, and the USGS MODSIM model for the Carson River). These "what if" scenarios serve the purpose of engaging water managers in collaboratively and iteratively assessing drought resilience. The integration of stakeholder-informed climate scenarios with these models is expected to simulate system-wide conditions with varied consequences for water user communities. As the research progresses and model results are shared, local water managers collaborate with scientists, and one another, to examine current and potential adaptation strategies. 
Table 1. Case study collaborative modeling research design. The collaborative modeling research design developed for this case study features a suite of standard primary data collection methods integrated with Extension outreach methods. The purpose of each method is to draw upon local knowledge and social learning to inform theoretically grounded hydrologic, operations, and economic models.

\begin{tabular}{|c|c|c|c|}
\hline Method & Purpose & Substance & Procedure \\
\hline Conduct stakeholder analysis & $\begin{array}{l}\text { Identify key local water managers } \\
\text { willing to participate in a Stakeholder } \\
\text { Affiliate Group that engages regularly } \\
\text { with scientists. }\end{array}$ & $\begin{array}{l}\text { Local water managers' interests/stake(s) in a river } \\
\text { system, interactions with others, and interest and capacity } \\
\text { to motivate local change strengthens resilience. }\end{array}$ & $\begin{array}{l}\text { Conduct face-to-face semi-structured interviews with } \\
\text { local water managers across the river system from } \\
\text { headwaters to terminus. }\end{array}$ \\
\hline Interview water managers & $\begin{array}{l}\text { Assess system resilience and adaptive } \\
\text { capacity per daily operational decisions } \\
\text { of local water managers. Use assessment } \\
\text { results to inform plausible climate } \\
\text { scenarios developed to purposefully } \\
\text { stress the river system. }\end{array}$ & $\begin{array}{l}\text { A baseline of system resilience is derived through } \\
\text { assessing adaptation actions taken under normal and } \\
\text { drought water supply conditions, perceived present and } \\
\text { future river system stressors, water policy preferences, } \\
\text { and existing communication and coordination networks. }\end{array}$ & $\begin{array}{l}\text { Facilitate discussions amongst science team to develop } \\
\text { interview survey questions to inform climate scenarios } \\
\text { and hydrologic model simulations; review, test, and } \\
\text { revise survey instrument; develop and test sampling } \\
\text { strategy to ensure stakeholder diversity; collect, code, } \\
\text { and analyze survey data; and share results. }\end{array}$ \\
\hline $\begin{array}{l}\text { Assess water right holders } \\
\text { decision-making }\end{array}$ & $\begin{array}{l}\text { Assess system resilience and adaptive } \\
\text { capacity under variable climate induced } \\
\text { water supply conditions and institutional } \\
\text { constraints simulated through } \\
\text { stakeholder informed climate scenarios. }\end{array}$ & $\begin{array}{l}\text { Local decisions, including risk aversion under climate } \\
\text { induced variable water supplies, populate economic } \\
\text { models, further inform hydrologic and operational model } \\
\text { simulations, and inform resource management strategies } \\
\text { and policy alternatives under climate uncertainty. }\end{array}$ & $\begin{array}{l}\text { Specify economic models; develop survey questions in } \\
\text { collaboration with research team and stakeholders; } \\
\text { review, test, and revise survey instrument; collect, } \\
\text { code, and analyze data; test and refine economic } \\
\text { models, and share results. }\end{array}$ \\
\hline $\begin{array}{l}\text { Plan, conduct and evaluate } \\
\text { workshop series }\end{array}$ & $\begin{array}{l}\text { Establish effective dialogue between } \\
\text { scientists and stakeholders to exchange } \\
\text { mutually beneficial information and } \\
\text { encourage social leaning. }\end{array}$ & $\begin{array}{l}\text { Effective communication, interaction, and information } \\
\text { exchange between scientists and stakeholders support } \\
\text { and refine science research and localize potential } \\
\text { adaptation strategies. }\end{array}$ & $\begin{array}{l}\text { Facilitate structured discussions involving scientists } \\
\text { and stakeholders; solicit stakeholder input; evaluate } \\
\text { research design and integrate results to continuously } \\
\text { improve quality of workshops and research design. }\end{array}$ \\
\hline Conduct focus group sessions & $\begin{array}{l}\text { Provide structured forum for continuous } \\
\text { dialogue between scientists and local } \\
\text { water managers to ground truth and } \\
\text { inform climate scenarios, hydrologic and } \\
\text { operational model simulations, and } \\
\text { economic model estimation. }\end{array}$ & $\begin{array}{l}\text { Ongoing information exchange between scientists and } \\
\text { key water managers supports social learning, further } \\
\text { informs research, monitors adaptation strategies, assesses } \\
\text { system resilience, improves research design, and } \\
\text { strengthens communication and relationships. }\end{array}$ & $\begin{array}{l}\text { Iteratively examine research results with stakeholders; } \\
\text { document operational challenges and responses to } \\
\text { climate scenarios while exploring emergent adaptation } \\
\text { strategies; test, evaluate, and refine collaborative } \\
\text { modeling research design. }\end{array}$ \\
\hline $\begin{array}{l}\text { Share research findings with } \\
\text { water managers through } \\
\text { Extension outreach }\end{array}$ & $\begin{array}{l}\text { Share case study research results with } \\
\text { water managers regarding resilience and } \\
\text { adaptive capacity of the river system } \\
\text { under climate uncertainty. }\end{array}$ & $\begin{array}{l}\text { Shared research findings support ongoing/iterative } \\
\text { participation in research and strengthens capacity to } \\
\text { adapt to climate uncertainty. }\end{array}$ & $\begin{array}{l}\text { Share research results via presentations and } \\
\text { discussions, in addition to outreach publications that } \\
\text { translate research findings for public use. }\end{array}$ \\
\hline
\end{tabular}




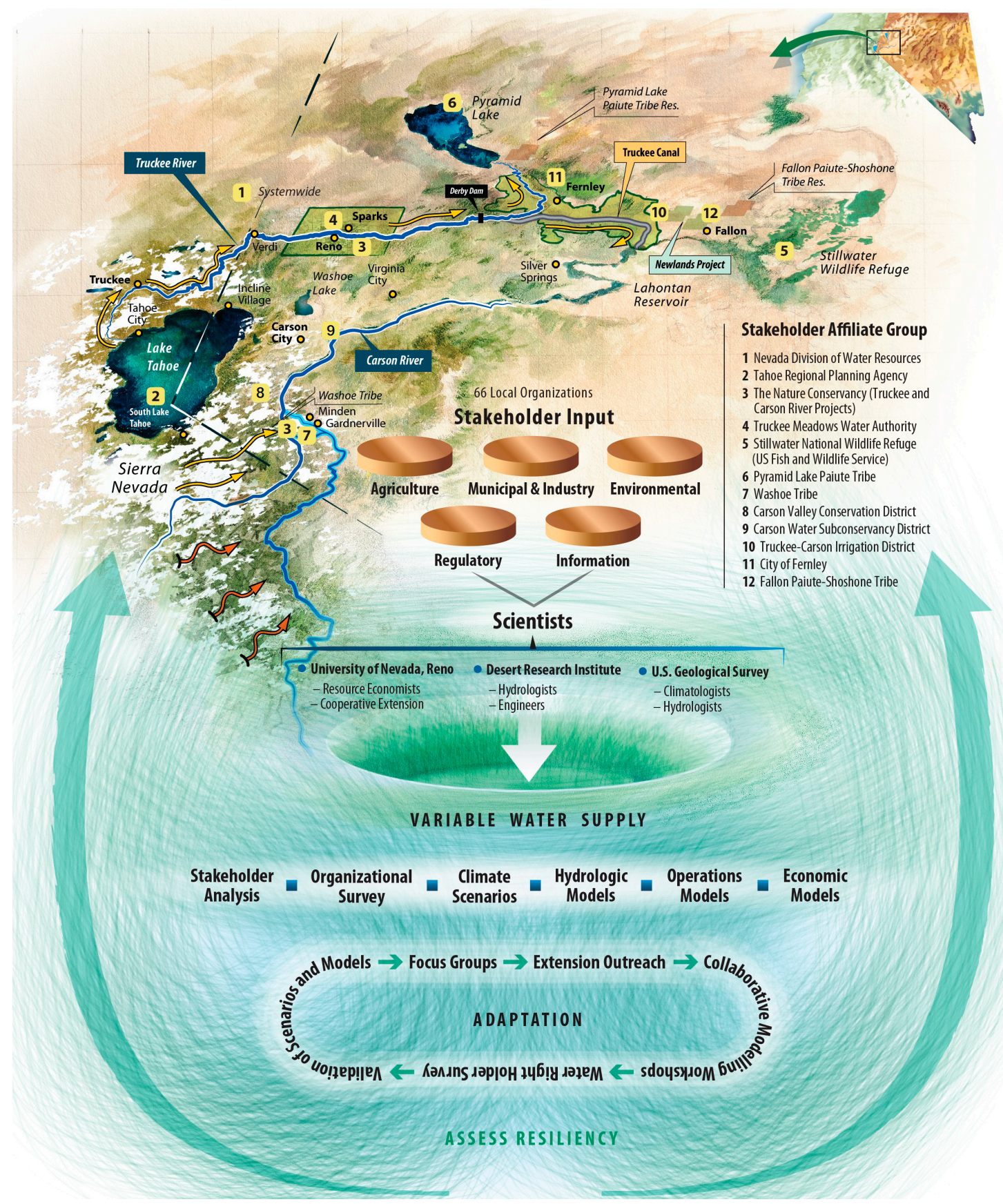

Figure 2. Case study collaborative modeling research design.

\section{Assessing Resiliency in the Truckee-Carson River System Case Study Area}

\subsection{Creating a Survey Instrument to Assess Drought Resiliency}

A set of questions was developed to assess the drought resiliency of the river system as seen through the lens of local water managers. Two challenges became apparent during the development of the survey instrument. The first challenge relates to the complexity of climate resilience as a concept; that is, to assess and arrive at an adequate picture of the river system, the assessment must capture information on both water managers' responsibilities and river system impacts and responses, during the present time and in the future. The second challenge involves the collaborative modeling research design itself, which requires balancing multiple and competing water uses and 
user perceptions with the information needs of scientists who represent multiple academic disciplines and perspectives.

To address these challenges, a mostly open-ended survey instrument was developed and intended for face-to-face semi-structured interviews with key representatives of local water management organizations within the case study area. A draft of the questionnaire was pre-tested by subsets of the targeted survey population. That is, the questionnaire was pre-tested by a panel of representative water managers in neighboring snow-fed watersheds excluded from this case study. The purpose of the pre-test was to identify missing items, evaluate content validity, and to check for clarity and comprehension of question items. The questionnaire was revised based upon the pre-test results.

The resulting survey instrument features 21 questions that assess local water managers' perceived drought risks as well as current and desired adaptation $[7,10,17,18,36,38,39]$. Questions were designed: (1) to characterize water management responsibilities and priorities under reduced water supplies; (2) to identify normal, moderate, and severe water supply shortage scenarios, or drought thresholds, that challenge routine operations; and (3) to explore changes necessary to improve the capacity of both the river system and local water managers to absorb and bounce back from shocks posed by continued climate uncertainty and long-term drought. Essentially, survey questions were developed specifically to draw upon local knowledge of the system to inform climate, hydrologic, and resource economics research. Additionally, questions were developed to engage local water managers in discussing system and organizational resiliency to drought. Table 2 summarizes and describes the survey question items and the use of information gathered [37].

\subsection{Sampling Procedure}

Two types of information are key to assessing community climate resilience and adaptive capacity: (1) specific information about local organizations that manage water in the Truckee-Carson River System, including their reliance upon the water resource, perceived risks posed by drought conditions, and current or potential adaptive responses; and (2) information regarding overall river system function across competing demands for ecosystem services placed upon the resource. Subsequently, the sampling procedure sought to obtain thorough information about the river system function from headwaters to terminus as well as water supply issues that challenge stakeholder communities reliant upon its waters. The sample was stratified by the two rivers that comprise the river system (Truckee and Carson), and by river system segments. These included the headwaters, middle reaches, lower reaches, desert terminus lake, and constructed system terminus [37].

Between March and August 2015, through face-to-face semi-structured interviews, researchers surveyed 66 key representatives of local water management organizations. These organizations were selected to achieve a normal spatial distribution across the Truckee-Carson River System from headwaters to terminus points as follows: Truckee River (26), Carson River (16); below the Truckee Canal (9), and Truckee-Carson system wide (both rivers) (15).

The water managers selected for interviews represent organizations that hold significant regulatory or water management responsibilities and/or interests. Essentially organizations were surveyed if they: (1) consume, deliver, protect or supply a large quantity of water (such as irrigation and regional utility districts); (2) can take action or pursue litigation that may have a significant impact on water management in the system; (3) possess systemic expertise on specific issues; (4) maintain roles that greatly influence systemic capacity to adapt; or (5) provide insight regarding the economic or jurisdictional impacts of location-specific water issues. 
Table 2. Resiliency assessment information purpose and uses. Survey sections are organized by types of questions developed to access local knowledge to inform climate, hydrologic, and resource economics research.

\begin{tabular}{|c|c|c|c|c|}
\hline Survey Sections & Types of Questions & $\begin{array}{l}\text { Climatologists, Hydrologists, } \\
\text { Engineers }\end{array}$ & Water Managers & Resource Economists \\
\hline $\begin{array}{l}\text { Identify water managers } \\
\text { per interest, responsibility } \\
\text { and/or spatial } \\
\text { representation across } \\
\text { river system }\end{array}$ & $\begin{array}{l}\text { Collect data by location, type of } \\
\text { organization, political level of } \\
\text { jurisdiction, management } \\
\text { responsibilities, ecosystem services } \\
\text { managed, and management priorities. }\end{array}$ & $\begin{array}{l}\text { Acquire information from local } \\
\text { water managers to develop } \\
\text { plausible climate scenarios for the } \\
\text { river system. }\end{array}$ & $\begin{array}{l}\text { Demonstrate that sampling strategy } \\
\text { represents spatially and interest } \\
\text { diverse organizations; analyze } \\
\text { survey responses to allow } \\
\text { stakeholders to compare their } \\
\text { responses with others. }\end{array}$ & $\begin{array}{l}\text { Classify water managers to ensure } \\
\text { sufficiently diverse sample in terms of } \\
\text { management responsibilities and } \\
\text { location within the river system. }\end{array}$ \\
\hline $\begin{array}{l}\text { Assess river system and } \\
\text { community resiliency }\end{array}$ & $\begin{array}{l}\text { Assess historical water supply } \\
\text { challenges including drought of record, } \\
\text { and assess current climate variability, } \\
\text { such as warming temperatures and } \\
\text { changes in seasonality. }\end{array}$ & $\begin{array}{l}\text { Climate scientist develops scenario } \\
\text { using survey responses; hydrologists } \\
\text { and engineers review responses on } \\
\text { ranges of water supply thresholds. }\end{array}$ & $\begin{array}{l}\text { Capture overall system resiliency } \\
\text { and learn about the challenges } \\
\text { confronting other water managers. }\end{array}$ & $\begin{array}{l}\text { Assess local organization and } \\
\text { community resiliency to } \\
\text { climate-induced variable } \\
\text { water supplies. }\end{array}$ \\
\hline $\begin{array}{l}\text { Improve understanding of } \\
\text { the river system }\end{array}$ & $\begin{array}{l}\text { Assess water management } \\
\text { decision-making under current } \\
\text { institutional constraints, climate change } \\
\text { opinion, present and future river } \\
\text { system stressors, communication } \\
\text { networks, and information sources. }\end{array}$ & $\begin{array}{l}\text { Scientists clarify study area } \\
\text { boundaries and model constraints. }\end{array}$ & $\begin{array}{l}\text { Learn about how others manage } \\
\text { their variable water supplies, } \\
\text { perceive river system stressors, and } \\
\text { who is talking with whom. }\end{array}$ & $\begin{array}{l}\text { Scientists clarify study area } \\
\text { boundaries and } \\
\text { institutional constraints. }\end{array}$ \\
\hline $\begin{array}{l}\text { Assess local } \\
\text { adaptation strategies }\end{array}$ & $\begin{array}{l}\text { Identify current and desired adaptation } \\
\text { strategies, planning horizons and the } \\
\text { current use of climate science } \\
\text { information within the organization. }\end{array}$ & $\begin{array}{l}\text { Conceptualize and simulate } \\
\text { management alternatives that } \\
\text { inform adaptation strategies. }\end{array}$ & $\begin{array}{l}\text { Learn how other water managers } \\
\text { across the system are adapting. }\end{array}$ & $\begin{array}{l}\text { Map adaptation strategies to build an } \\
\text { understanding of adaptive capacity } \\
\text { across the system. }\end{array}$ \\
\hline $\begin{array}{l}\text { Evaluate operational and } \\
\text { water policy preferences }\end{array}$ & $\begin{array}{l}\text { Probe discussion on potential } \\
\text { operational and policy decisions } \\
\text { including infrastructure improvements, } \\
\text { additional storage, water right } \\
\text { exchange flexibility, conservation, and } \\
\text { research and information needs. }\end{array}$ & $\begin{array}{l}\text { Plan hydrologic and operations } \\
\text { model simulations based on water } \\
\text { managers' interest in changes to } \\
\text { water operations, including artificial } \\
\text { recharge, additional reservoirs and } \\
\text { aquifer storage and recovery. }\end{array}$ & $\begin{array}{l}\text { Learn about needs and preferences } \\
\text { of other water managers in } \\
\text { the system. }\end{array}$ & $\begin{array}{l}\text { Gather local knowledge and } \\
\text { preferences concerning water policy } \\
\text { alternatives to strengthen } \\
\text { adaptive capacity. }\end{array}$ \\
\hline
\end{tabular}




\subsection{Data Analysis}

Qualitative data resulting from open-ended questions were examined using content analysis, a method commonly used to objectively document patterns and trends to obtain a quantitative description [40] and then descriptively coded [41,42]. Intercoder reliability assessment was undertaken to ensure minimization of coder bias or random error arising from judgments made about categories and themes emerging from the qualitative data sets. Intercoder reliability is a quantitative measure of agreement between multiple coders with regard to the ways in which codes are applied to qualitative data [43]. The coded data were analyzed using basic descriptive statistics and summarized using content from transcripts as needed. Per University of Nevada, Reno Office of Human Research Integrity Internal Review Board approval for this survey research involving human subjects, only the de-identified cumulative results are reported here.

\section{Assessment Results}

\subsection{Characteristics of Water Management Organizations Surveyed}

While the sampling procedure assured reasonable spatial distribution of water managers across the river system, the decision-making level of the majority of the organizations surveyed were classified as local $(71 \% ; n=66)$, followed by federal $(20 \%)$ and state $(9 \%)$. Local organizations included county, municipal, public/private, tribal, water utility/treatment and nongovernmental organizations, including environmental interest groups. While not targeted, the comparatively larger participation by local water management organizations supports the underlying concept of the collaborative modeling research design for this case study. That is, drought resiliency arises from local awareness for change and local action.

Researchers asked each of the 66 water managers to describe their organizations' primary water management responsibilities in the Truckee-Carson River System. Responses typify the diversity and density of water use groups in the case study area. The majority of the 66 respondents described their primary responsibilities as environmental $(n=18)$, followed by municipal and industrial $(n=15)$, planning $(n=14)$, regulatory and information $(n=11)$, and agricultural $(n=8)$.

Environmental responsibilities included water quality protection and a variety of ecosystem services, including recreation, wildlife habitat, and riparian and restoration management. Municipal and industrial organizations noted responsibilities related to domestic and industrial water supply, wastewater treatment, and include public and private utilities that engage in related water supply functions. Planning organizations described responsibilities related to local and regional planning in addition to economic development and related research activities. Regulatory and information organizations have system wide oversight and typically engage in research, monitoring, and data collection activities at the river system scale. Agricultural organizations described responsibilities pertinent to maintaining irrigated agricultural production or provide support to agricultural production activities at the farm or ranch scale.

Researchers presented a list of possible ecosystem services that the Truckee-Carson River System provides and asked water managers to identify those services for which their organization is responsible. Of those who responded $(n=58), 39$ reported that their organization's major responsibility is to manage for water quality assurance. This was followed by ecological restoration $(n=32)$ and recreation $(n=32)$, municipal water supply $(n=29)$ and flood control $(n=29)$, and wildlife $(n=28)$ and domestic wells $(n=28)$.

Researchers asked water managers to select from a list of self-identified water management responsibilities the top three (first, second and third) priorities during drought conditions when water supplies are low. Of those who responded $(n=49)$, most respondents assigned first priority to managing water supply for drinking or human consumption $(n=15)$. This was followed by agricultural water supplies $(n=8)$, ecological restoration $(n=7)$, and water quality protection or maintenance $(n=6)$. 
The second priority assigned was wildlife $(n=8)$, followed by industrial water supplies, water quality, and ecological restoration $(n=7$, respectively).

\subsection{Challenges Identified as a Result of Water Supply Shortages}

Water managers were asked to describe management challenges that occur during a "normal" water year, followed by challenges that occur in years where water supply shortages are "moderate" and "severe". Depending on water managers' roles and responsibilities, respondents defined a normal water year as a year in which water supplies represent average flows, a year in which snowpack is measured at $100 \%$ of normal, or a year in which all water rights and allocations are met.

More than half of respondents $(58 \%, n=55)$ reported that their organizations faced water management-related challenges during normal water supply years. Challenges were most often associated with water delivery, due to current infrastructure constraints, followed by water scarcity and administering current water policy.

When asked to describe moderate and severe supply shortages, and subsequent challenges, responses varied based on the primary water management responsibility of the organization. Moderate and severe supply shortages are reported as ranges to capture drought thresholds defined by water managers that possess and/or manage water rights that include municipal and industrial, planning, agricultural, and environmental organizations.

Municipal water managers, which include representatives of municipal, industrial, and planning organizations, defined moderate supply shortages as $10 \%-50 \%$ allocation for $1-3$ years, and indicated that associated challenges would be addressed through existing drought preparedness planning horizons of 2-10 years. For municipal organizations, availability of surface and groundwater storage helps to alleviate supply challenges by offsetting shortages during drought conditions. Respondents often suggested that moderate drought, or periodically moderate water supply shortages, is to be expected in desert climates. Municipal water managers identified key challenges related to water quality maintenance, negative economic impacts, increased wildfire risk, increased reliance on groundwater, and challenges meeting peak summer demand as well as delivering water supplies.

Municipal water managers defined severe water supply conditions as 5\%-20\% allocation for 2-10 years. While water utility managers described how their planning horizons accounted for longer drought periods, severe drought conditions that exceeded their planning horizon would exacerbate challenges, making it particularly difficult to satisfy current water demand under the river system's current policy regime and regulatory structure. Water managers indicated that under such severe drought conditions, immediate and necessary changes would include mandatory reduction in landscape irrigation. Of note, a longer period of severe shortage years (up to 10 years) would only be absorbed under structural change, including loss of water-intensive industries and an "end" to landscape irrigation. Currently, municipal and commercial landscape irrigation comprises at least $50 \%$ of municipal water demand in the case study area.

Agricultural water managers defined moderate supply shortages as $40 \%-90 \%$ allocation for 2-4 years and described how farmers and ranchers effectively cope with incremental water supply shortages for short periods using currently available farm-level adaptations. However, agricultural productivity diminishes with an increase in duration of drought, due partly to declining soil moisture inhibiting water infiltration through the irrigation season. Challenges for agricultural water managers related to decreased water supply included changes in economic stability, groundwater supply shortages due to increased reliance on pumping, and complexities related to changing place of use for water rights that might prohibit farmers from irrigating only the most productive lands while fallowing marginally productive lands.

Agricultural water managers defined severe drought as $20 \%-50 \%$ allocation for $1-2$ years, representing a roughly $50 \%$ reduction in both water allocation and duration to withstand these conditions. Severe drought conditions challenge irrigation districts' abilities to deliver the full water duty due to increasingly drier soils absorbing water that is conveyed through earthen delivery canals 
and ditches, and an increase in invasive weed infestations due to forced fallowing of fields. Agricultural water managers reported that for agricultural water users, depending on the actual allocation received, even a one-year drought could be considered severe.

Environmental water managers defined moderate drought as 30\%-75\% allocation for $2-3$ years. Challenges under moderate supply shortages related to sustaining and managing native vegetation, riparian habitat, and water quality as well as watershed scale issues from increased wildfires and associated ecological impacts. Water managers noted that diminishing water supplies over longer time periods stresses riparian restoration and rehabilitation projects to the point where migratory wildlife abandon these areas and the rates of disease and mortality increase. A supply shortage involving $10 \%-50 \%$ allocation lasting three years or longer could be considered severe and detrimental to species diversity and habitat health, challenging operations to a greater extent.

While regulatory and information organizations are not challenged by water supply shortages in the same way as municipal, agricultural, and environmental organizations, water managers provided input regarding moderate and severe shortages and subsequent challenges. Rather than defining explicit drought thresholds, respondents described system wide drought indicators, including information provided by the United States Drought Monitor, documented Lake Tahoe rim levels, and reported declines in domestic well levels. Challenges included increased concentration of water quality contaminants, difficulty in tracking voluntary reductions in water use, and lack of information and monitoring related to changing water use and demand.

For most water managers surveyed, challenges associated with moderate drought are exacerbated under severe drought, regardless of type of organization. Concerns voiced consistently included deteriorating water quality, irreversible negative economic impacts, and groundwater supply shortfalls due to increased groundwater pumping when surface supplies are insufficient.

Researchers asked water managers if temperature matters, and if so, how it matters. The majority of respondents $(83 \%, n=64)$ reported that temperature matters. Of those who described how temperature matters $(n=53), 37$ noted warming temperatures may increase the likelihood of precipitation falling as rain rather than snow, impacting snowpack accumulation, and result in earlier snowpack melt which will affect the timing of water supply availability. These respondents noted additionally that warming temperatures would result in environmental impacts, including diminishing soil moisture content, increased risk of wildfire, and increased wildlife water demand. Potential economic impacts were noted due to revenue losses resulting from a shift in timing of water supply availability challenging the ability to satisfy municipal and/or irrigation water demand.

In order to further localize descriptions of severe drought conditions and establish climate thresholds for the river system, water managers were asked to identify the worst drought to date their organization had faced. Of those water managers who responded $(n=58), 60 \%$ reported the current drought period (2012-2015) as the worst, with 40\% describing droughts of the recent past, particularly the 1987-1994 drought of record.

\subsection{Adaptation Strategies to Address Water Supply Shortages}

When asked how important climate change is to the river system, 79\% of water managers surveyed $(n=66)$ reported it was very important, and $11 \%$ reported it was important. Nearly all water managers $(92 \%, n=59)$ reported that discussions within their organizations are underway concerning climate change adaptation, and $75 \%(n=63)$ reported that their organizations are already implementing one or more drought adaptation strategies. Of those respondents who described their drought adaptation strategies $(n=53)$, more than half $(n=27)$ reported focusing primarily on demand management, such as reducing recruitment of water-intensive industry to the region and reducing residential and commercial irrigated landscaping. Others reported a focus on supply enhancement $(n=18)$ including seeking new groundwater sources and treating marginal waters. Still others expressed a need for increased science and information $(n=12)$, modifying existing policy and regulations $(n=10)$, and improved communication and coordination with other local organizations $(n=9)$. 
When asked explicitly if there were any coordination problems across the river system, constraining the ability to adapt, more than half of those who responded $(59 \%, n=56)$ emphasized that regional communication is problematic and improvements are needed. Of those who stated regional communication could improve $(n=33), 19$ described the need for facilitated coordination across local water management organizations. Nearly a fifth of those same respondents indicated that coordination must improve specifically between upstream and downstream users.

Water managers were asked to describe the kinds of desired changes to water management that might improve adaptive capacity. Of those who responded to this question $(n=54)$, more than half $(n=33)$ desired changes to existing water policy to allow more flexibility for managing water during below average years. Many respondents also desired improved coordination and communication among water managers $(n=14)$, and increased information and public education about climate change and drought adaptation strategies $(n=13)$. Several also described the need for new policies to enhance supply $(n=8)$, such as reusing treated effluent, and others indicated new policies are necessary to manage demand $(n=7)$, such as stricter enforcement of conservation mandates.

When asked what are the greatest stressors on the river system presently, the majority of those who responded $(n=63)$ answered drought $(n=39)$, followed by population and economic growth $(n=26)$ (Figure 3$)$. These results were nearly identical regarding future stressors. Several water managers noted that water delivery infrastructure and water management policies comprise both present and future stressors. To address these challenges, respondents suggested repairing or replacing antiquated and degrading infrastructure, building additional water treatment infrastructure to enhance supplies, and modifying current water policy.

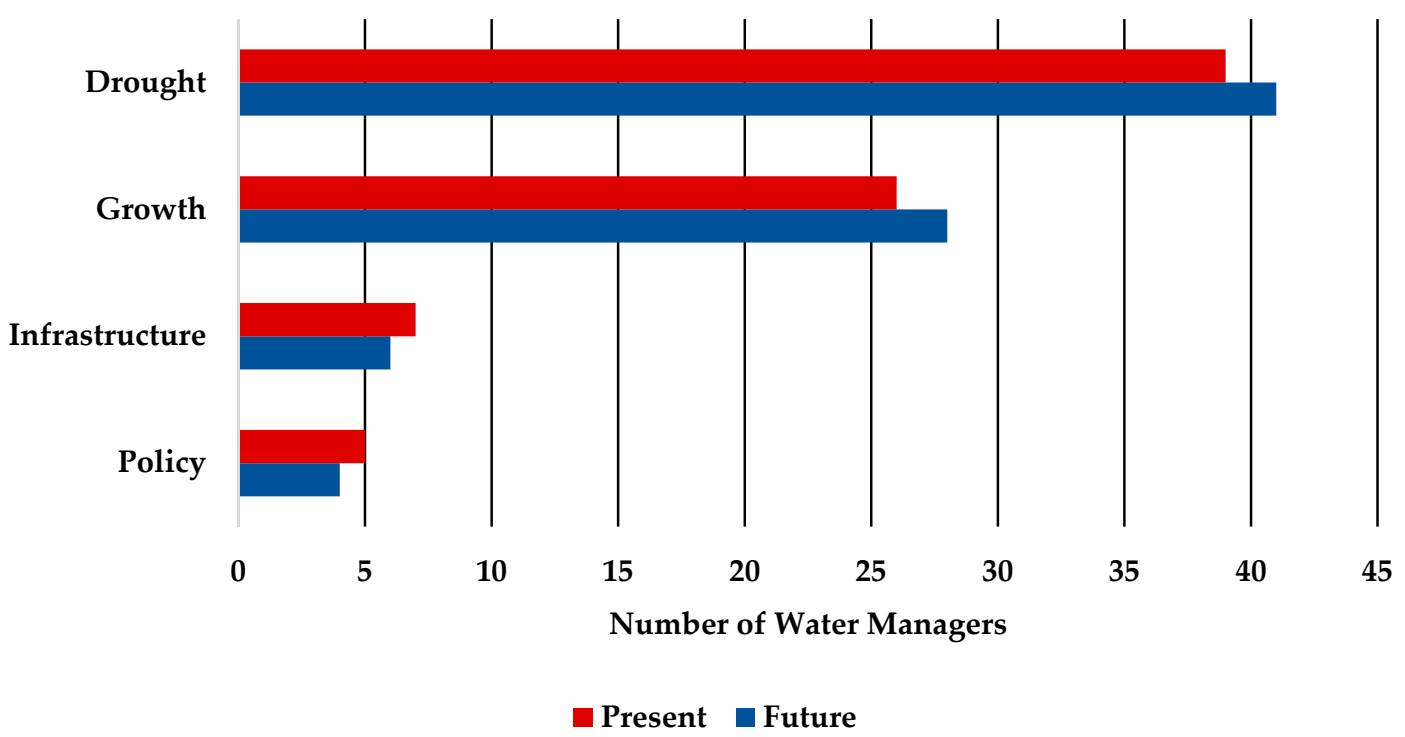

Figure 3. Present and future stressors on the Truckee-Carson River System. Water managers selected up to two stressors.

To gauge the potential for future adaptive capacity, researchers asked water managers, if there were no policy constraints, what changes would they make to better manage water resources. More than a third of water managers who answered the question $(34 \%, n=61)$ suggested modifying prior appropriation doctrine to allow for greater flexibility and efficiency in using allocated water rights such as temporary water leasing/banking programs and irrigating only the most productive lands. Other immediate changes described by respondents included recruiting less water-intensive industry to the region $(n=25)$, decreasing current water consumption and use patterns $(n=17)$, increasing coordination and communication among water managers $(n=17)$, and improving water delivery infrastructure $(n=16)$. Several respondents $(n=7)$ indicated the need to revise the policy-making 
process as it pertains to water allocations, including revisiting historically fixed calendar dates that regulate the timing of releases of water supplies.

\subsection{Development of Stakeholder Informed Climate Scenario}

Local water managers who were surveyed agreed that Truckee-Carson River System water supplies are vulnerable to variable snowpack accumulation and timing of snowmelt. They identified the current 2012-2015 drought as the worst drought of memory and most challenging to date, followed by the 1987-1994 drought of record.

Facilitated discussion during the first of six biannual workshops, convening scientists with Stakeholder Affiliate Group participants, confirmed consensus that an extended drought scenario with warming temperatures posed plausible risks to river system function and the socioeconomic, cultural, and environmental wellbeing of communities in the surrounding region. Subsequently, the first climate scenario for this collaborative modeling case study extends the 2012-2015 drought to 13 years by concatenating the historical climate record from the 1987-1994 drought.

A second version of the climate scenario adds a $2.5^{\circ} \mathrm{C}$ temperature increase to the 13 -year drought scenario, based on projected global warming trends [44]. These two climate scenarios provide daily precipitation and daily maximum and minimum temperature as meteorological data inputs to the hydrologic models that simulate surface and groundwater flows in the river system under these conditions. Additionally, river system operations and diversions are simulated using these hypothetical flows.

\section{Discussion}

The research presented here provides measured insight into local water managers' perceptions of drought resiliency in the Truckee-Carson River System. The findings are reported within the context of the collaborative modeling research design developed for this case study. Notable findings from interviews conducted with 66 local water managers include $79 \%$ of water managers indicating that indeed climate change is very important to the river system, with $11 \%$ rating it as important. Nearly all water managers reported that their organization is either contemplating climate change adaptation or already implementing drought adaptation strategies. These include improving communication and coordination with other local organizations, improving data collection and monitoring, and increasing overall drought contingency planning.

Water managers suggested several changes to improve their ability to adapt. Changes included modifying prior appropriation doctrine to allow for greater flexibility in managing allocated water; reducing water-intensive industry and residential landscaping; incentivizing water conservation; and increasing and improving coordination and communication among water managers. Preferred policy actions to manage water resources more effectively involved financing improvements to existing water delivery infrastructure and conjunctively managing surface and groundwater resources. Additional policy actions included modifying current water law to facilitate temporary water leasing programs, stacking water rights to irrigate only the most productive agricultural lands, and fallowing marginal lands under extended drought conditions.

Local water managers emphasized repeatedly that coordination and communication among water users need to improve specifically between upstream and downstream users. Water managers requested that researchers provide ongoing information on local climate impacts, adaptation strategies and options, and increase public education on climate adaptation.

Consultations with water managers informed two climate scenarios constructed by: (1) concatenating the two most severe historical droughts of record; and (2) raising temperatures by $2.5^{\circ} \mathrm{C}$. Contextually, as respondents rated the severity of these two drought periods, and their concern regarding warming temperatures, they commented on factors that influence their ratings. These comments focused on concerns regarding recent local efforts to recruit new industry to the region and subsequent population growth, increasing the demand for already limited water supplies. More than two thirds of water 
managers surveyed expressed concerns with the consequences of warming temperatures with regards to reduced snowpack, precipitation falling as rain rather than as snow, earlier spring snowmelt, and increased evapotranspiration rates.

The preliminary hydrologic model simulations provide a range of possible outcomes related to both surface water flows and groundwater recharge. Additionally, operations models are used to simulate water withdrawals and determine if water rights are met under these climate scenarios utilizing the current institutional arrangements that govern water allocations throughout the river system, including prior appropriation doctrine, federal court decrees, and negotiated settlement agreements.

As the collaborative modeling research progresses, results are shared with the Stakeholder Affiliate Group during biannual workshops. The goal of these workshops is to facilitate ongoing discussion among scientists and local water managers concerning the hydrologic and operational impacts of the two climate scenarios and subsequent adaptation strategies. Future workshops will feature the results of economic models to better understand water right holders' decisions to manage risk under drought conditions. The workshops provide an opportunity to iterate and validate findings, and prioritize research moving forward.

The resiliency assessment results reported here represent the first step in gathering stakeholder input as part of this case study collaborative modeling research design. Researchers strive to interact with local water managers as often as needed to understand how water supply conditions and adaptations change as a function of time and climate uncertainty. These interactions include structured workshops and focus group discussions that serve to iteratively assess ongoing water management information needs provided through hydrologic and operation model outputs to date, identifying adaptation opportunities and constraints, and collaboratively selecting alternative water management scenarios to simulate through these models. By continuing to engage with key local water managers through structured workshops and focus group discussions, researchers are collecting explicit data toward a more comprehensive assessment of resiliency system wide. Researchers will continue to revise and document this collaborative modeling research design as necessary based on the evaluative feedback received from local water managers.

\section{Conclusions}

Research progress and evaluative efforts to date demonstrate that the collaborative modeling research design developed for the Truckee-Carson River System case study effectively convenes scientists and local water managers to assess drought resiliency. When designed, implemented, and revised as necessary, participatory research approaches can produce findings immediately useful to snow-fed river dependent communities in the Western United States striving to adapt to climate uncertainty surrounding prolonged and/or severe drought. Lessons learned to date from this case study may inform similar participatory research approaches interested in understanding how local water managers view and adapt to water supply variability. The set of applied methods described here may be catered to similar basins to initiate an assessment of drought resiliency. Similarly, this involves identification of key stakeholder representatives, their perceived water management challenges, and adaptation strategies.

A key lesson is the importance of scientists' early engagement with local stakeholders, which helps to clarify case study boundaries, identify research questions of local interest, and identify a core group of key stakeholders for ongoing participation in the research activities. This early engagement sets the stage for a transparent and responsive process, which aids in building trust in the research design as demonstrated through scientists seeking and incorporating local knowledge and preferences. Related to this transparency is the need to acknowledge power disparities that may exist among stakeholder communities including historically marginalized groups with high stakes in sustaining water resources. A thorough stakeholder analysis should address these considerations and is a critical component of the research design. 
Efforts to identify best practices are necessary including, for example, effective methods to convene scientific experts across multiple disciplines to collaborate in a consistently productive manner. Similarly, application of best practices is necessary to ensure effective methods for convening stakeholders who represent divergent and competing demand for limited water supplies.

Scientists and stakeholders alike may have very specific ideas regarding the outcomes they perceive as useful or desirable from a participatory research approach. At the conclusion of the resiliency assessment interviews, local water managers were asked what they hope to get out of this collaborative modeling project. Of those who responded $(n=66), 90 \%$ requested science-based information or improved communication to improve their respective individual adaptive capacity. In fact, $49 \%(n=59)$ of these same water managers specifically requested the results of this case study, in addition to public education focused on adaptation. Regardless of stakeholders' need for science-based research information at the river system and community scale, scientists must also satisfy professional expectations that they conduct high quality research with generalizable and publishable findings. Therefore, scientists may see themselves as stakeholders in the context of participatory research and assume certain risks as well [45].

It is essential to identify and clarify such expectations early on while also regularly reporting progress, interacting and communicating effectively, and exchanging mutually beneficial information. Stakeholder information needs, and subsequent research activities and findings, must be clearly communicated, and translated as necessary, so as to optimize their usefulness to both scientists and local stakeholders [46]. For these reasons, it is necessary to evaluate the quality of interaction and communication that occurs [47].

While objectively documented outcomes and impacts of collaborative modeling remain few in number, limited evidence suggests this research design has the potential to improve access to climate science research and subsequent adaptation at the river system and community scale $[24,48,49]$. Criteria to assess research outcomes include improvements in communication, networking, and relationships, and acknowledgement that as a result of the research, an expanded set of solutions emerge to help local stakeholders address climate induced resource challenges [22].

Additional research must test claims that collaborative modeling, as an example of a participatory research design, increases adoption and diffusion of innovative ideas that better address local information needs [36]. Specifically, research is needed to compare and contrast the processes and outcomes of similar case studies in order to examine methods enlisted to facilitate social learning among stakeholders and scientists and to improve collaborative and participatory research [50].

It should be noted that collaborative modeling is labor intensive and requires significantly more time and resources than top-down research approaches. Continuously monitoring the research design to identify opportunities for quality improvement requires ongoing evaluation of each method included. It also requires that researchers remain flexible, revising methods as needed.

As described here, a key component of this collaborative modeling research design is to systematically engage local water managers in the process of identifying plausible climate scenarios, which are then used to model hydrologic and operational outcomes for the river system. Iterative integration of stakeholder informed climate scenarios with these models is expected to simulate system wide conditions with varied consequences for water user communities. By presenting model results as a function of local stakeholder knowledge and perspectives, and driving subsequent iterations based on information needs, findings from this case study are expected to be relevant and useful to local water managers toward drought adaptation.

Additional research activities slated for this case study will continue to simulate hydrologic flows and operations under plausible climate scenarios and begin to explore drought adaptations. Research will also examine the decisions of individual agricultural water users as economic agents to mitigate risk under climate induced variable water supply conditions. Given the diversity and spatial distribution of these water management organizations across the river system, additional analysis is necessary to better understand how drought thresholds motivate adaptation. 
As this case study progresses, ongoing evaluative efforts will identify the extent to which research activities consistently address the information needs of competing water user interests involved. Research outcomes should contribute to the development of a viable portfolio of adaptation strategies to enhance drought resiliency in the Truckee-Carson River System, as representative of other snow-fed dependent regions in the Western United States and similar arid regions elsewhere.

Acknowledgments: Research is funded by a grant from the National Science Foundation (NSF) Division of Earth Sciences Water Sustainability and Climate program (award\# 1360506). The grant covers the cost of this publication. Acknowledgement to the Truckee-Carson River water managers, Stakeholder Affiliate Group participants, and scientists who make our collaborative modeling research design possible. Acknowledgement to Ron Oden for assistance with graphic design (Figures 1 and 2) and Karen Simpson for assistance with interviews.

Author Contributions: Loretta Singletary conceived of the collaborative modeling research design featured in the Truckee-Carson River System case study and has been lead on the primary data collection and outreach activities reported in this paper. Kelley Sterle scheduled the interviews and assisted with primary data collection, data analysis, and reporting. Loretta Singletary and Kelley Sterle collaborated on the text of this paper and concept graphics.

Conflicts of Interest: The authors declare no conflict of interest.

\section{References}

1. Stewart, I.T. Changes in snowpack and snowmelt runoff for key mountain regions. Hydrol. Process. 2009, 23, 78-94. [CrossRef]

2. Dettinger, M.D.; Udall, B.; Georgakakos, A. Western water and climate change. Ecol. Appl. 2015, 25, $2069-2093$. [CrossRef] [PubMed]

3. Georgakakos, A.; Fleming, P.; Dettinger, M.; Peters-Lidard, C.; Richmond, T.; Reckhow, K.; White, K.; Yates, D. Climate Change Impacts in the United States: Third National Climate Assessment; Melillo, J.M., Richmond, T., Yohe, G.W., Eds.; U.S. Global Change Research Program: Washington, DC, USA, 2014; pp. 69-112.

4. Intergovernmental Panel on Climate Change (IPCC). Summary for Policymakers. In Climate Change 2013: The Physical Science Basis. Contribution of Working Group I to the Fifth Assessment Report of the Intergovernmental Panel on Climate Change; Cambridge University Press: Cambridge, UK; New York, NY, USA, 2013; pp. 1-29.

5. Mankin, J.S.; Viviroli, D.; Singh, D.; Hoekstra, A.Y.; Diffenbaugh, N.S. The potential for snow to supply human water demand in the present and future. Environ. Res. Lett. 2015, 10, 114016. [CrossRef]

6. Intergovernmental Panel on Climate Change (IPCC). Managing the Risks of Extreme Events and Disasters to Advance Climate Change Adaptation; A Special Report of Working Groups I and II of the Intergovernmental Panel on Climate Change; Cambridge University Press: Cambridge, UK; New York, NY, USA, 2012; Volume 1.

7. Aldrich, D. Building Resilience: Social Capital in Post-Disaster Recovery; The University of Chicago Press: Chicago, IL, USA, 2012.

8. Simmie, J.; Martin, R. The economic resilience of regions: Towards an evolutionary approach. Camb. J. Reg. Econ. Soc. 2010, 3, 27-43. [CrossRef]

9. McGinnis, M.D.; Ostrom, E. Social-ecological system framework: Initial changes and continuing challenges. Ecol. Soc. 2014, 19, 30. [CrossRef]

10. Walker, B.; Salt, D. Resilience Practice: Building Capacity to Absorb Disturbance and Maintain Function; Island Press: Washington, DC, USA, 2012.

11. Folke, C.; Carpenter, S.R.; Walker, B.; Scheffer, M.; Chapin, T.; Rockström, J. Resilience Thinking: Integrating Resilience, Adaptability and Transformability. Ecol. Soc. 2010, 15, 299-305. [CrossRef]

12. Forsyth, T.; Schomerus, M. Climate Change and Conflict: A Systematic Evidence Review. Available online: http://eprints.lse.ac.uk/56352/1/JSRP_Paper8_Climate_change_and_conflict_Forsyth_Schomerus_ 2013.pdf (accessed on 5 October 2016).

13. Schlüter, M.; Tavoni, A.; Levin, S. Robustness of norm-driven cooperation in the commons. Proc. R. Soc. Biol. Sci. 2016, 283, 116-120. [CrossRef] [PubMed]

14. De Stefano, L.; Duncan, J.; Dinar, S.; Stahl, K.; Strzepek, K.M.; Wolf, A.T. Climate change and the institutional resilience of international river basins. J. Peace Res. 2012, 49, 193-209. [CrossRef] 
15. Ekstrom, J.A.; Moser, S.C. Institutions as key element to successful climate adaptation processes: Results from the San Francisco Bay area. In Successful Adaptation to Climate Change: Linking Science and Policy in a Rapidly Changing World; Moser, S.C., Boykoff, M.T., Eds.; Routledge: London, UK, 2013; pp. 97-113.

16. Dinar, A.; Blankespoor, B.; Dinar, S.; Kulukurasuriya, P. The Impact of Water Supply Variability on Treaty Cooperation between International Bilateral River Basin Riparian States; World Bank Policy Research Working Paper No. 5307; Elesvier: Amsterdam, The Netherlands, 2010; Volume 12, pp. 1-44.

17. Villamor, G.B.; Palomo, I.; Santiago, C.A.L.; Oteros-Rozas, E.; Hill, J. Assessing stakeholders' perceptions and values towards social-ecological systems using participatory methods. Ecol. Process. 2014, 3, 22. [CrossRef]

18. Hinkel, J.; Bots, P.W.G.; Schluter, M. Enhancing the Ostrom social-ecological system framework through formalization. Ecol. Soc. 2014, 19, 1-19. [CrossRef]

19. Ashwill, B.M.; Flora, C.; Flora, J. Building Community Resilience to Climate Change: Testing the Adaptation Coalition Framework in Latin America. Available online: http:/ / siteresources.worldbank.org/ EXTSOCIALDEVELOPMENT/Resources/244362-1232059926563/5747581-1239131985528/AdaptationCoalition-Framework-Latin-America_web.pdf (accessed on 5 October 2016).

20. Klenk, N.L.; Meehan, K.; Pinel, S.L.; Mendez, F.; Lima, P.T.; Kammen, D.M. Stakeholders in climate science: Beyond lip service? Science 2015, 743, 743-744. [CrossRef] [PubMed]

21. Meadow, A.M.; Ferguson, D.B.; Guido, Z.; Horangic, A.; Owen, G.; Wall, T. Moving toward the deliberate co-production of climate science knowledge. Weather Clim. Soc. 2015, 7, 179-191. [CrossRef]

22. Campos, I.S.; Alves, F.M.; Dinis, J.; Truninger, M.; Vizinho, A.; Penha-Lopes, G. Climate adaptation, transitions, and socially innovative action-research approaches. Ecol. Soc. 2016, 21, 13. [CrossRef]

23. Beall King, A.; Thornton, M. Staying the course: Collaborative modeling to support adaptive and resilient water resource governance in the Inland Northwest. Water 2016, 8, 232. [CrossRef]

24. Langsdale, S.; Beall, A.; Bourget, E.; Hagen, E.; Kudlas, S.; Palmer, R.; Tate, D.; Werick, W. Collaborative modeling for decision support in water resources: Principles and best practices. J. Am. Water Resour. Assoc. 2013, 49, 629-638. [CrossRef]

25. Ensor, J.; Harvey, B. Social learning and climate change adaptation: Evidence for international development practice. Wiley Interdiscip. Rev. Clim. Chang. 2015, 6, 509-522. [CrossRef]

26. McGreavy, B.; Lindenfeld, L.; Bieluch, K.H.; Silka, L.; Leahy, J.; Zoellick, B. Communication and sustainability science teams as complex systems. Ecol. Soc. 2015, 20, 2. [CrossRef]

27. Nauwelaers, C. Intermediaries in regional innovation systems: Role and challenges for policy. In Handbook of Regional Innovation and Growth; Cooke, P., Bjørn, A., Boschma, R., Martin, R., Schwartz, D., Tödtling, F., Eds.; Edward Elgar Publishing: Cheltenham, UK, 2011; pp. 467-481.

28. Funfgeld, H.; McEvoy, D. Resilience as a useful concept for climate change adaptation? Plan. Theory Pract. 2012, 13, 299-333. [CrossRef]

29. Kleppe, J.A.; Brothers, D.S.; Kent, G.M.; Biondi, F.; Jensen, S.; Driscoll, N.W. Duration and severity of Medieval drought in the Lake Tahoe Basin. Quat. Sci. Rev. 2011, 30, 3269-3279. [CrossRef]

30. Wilds, L.J. Water Politics in Northern Nevada: A Century of Struggle, 2nd ed.; University of Nevada Press: Reno, NV, USA, 2014.

31. Horton, G. A Chronological History of Lake Tahoe and the Truckee River and Related Water Issues: A Publication in the Nevada Water Basin Information and Chronology Series. Available online: http://water.nv.gov/mapping/chronologies/truckee/ (accessed on 5 August 2016).

32. Foley, J.R. In Defense of Self: Identity and Place in Pyramid Lake Paiute History. Master's Thesis, University of Nevada, Reno, NV, USA, 2008.

33. McDonald, G.M. Water, climate change, and sustainability in the southwest. Proc. Natl. Acad. Sci. USA 2010, 107, 21256-21262. [CrossRef] [PubMed]

34. Howells, M.; Hermann, S.; Welsch, M.; Bazilian, M.; Segerström, R.; Alfstad, T.; Gielen, D.; Rogner, H.; Fischer, G.; van Velthuizen, H.; et al. Integrated analysis of climate change, land-use, energy and water strategies. Nat. Clim. Chang. 2013, 3, 621-626. [CrossRef]

35. Ferguson, I.M.; Maxwell, R.M. Human impacts on terrestrial hydrology: Climate change versus pumping and irrigation. Environ. Res. Lett. 2012, 7, 44022. [CrossRef]

36. Reed, M.S. Stakeholder participation for environmental management: A literature review. Biol. Conserv. 2008, 141, 2417-2431. [CrossRef] 
37. Singletary, L.; Sterle, K.; Simpson, K. Assessing the Climate Resiliency and Adaptive Capacity of the Truckee-Carson River System: Results of a Survey of Local Organizations; University of Nevada Cooperative Extension Special Publication: Reno, NV, USA, 2016; p. SP-16-03.

38. Whateley, S.; Steinschneider, S.; Brown, C. A climate change range-based method for estimating robustness for water resources supply. Water Resour. Res. 2014, 50, 8944-8961. [CrossRef]

39. Brooks, N.; Adger, W.N.; Kelly, P.M. The determinants of vulnerability and adaptive capacity at the national level and the implications for adaptation. Glob. Environ. Chang. 2005, 15, 151-163. [CrossRef]

40. Rossman, G.B.; Rallis, S.F. An Introduction to Qualitative Research. Learning in the Field, 4th ed.; Sage Publications: Thousand Oaks, CA, USA, 2016.

41. Saldaña, J. The Coding Manual for Qualitative Researchers; Sage Publications: Thousand Oaks, CA, USA, 2009.

42. Miles, M.B.; Huberman, A.M.; Saldana, J. Qualitative Data Analysis: A Methods Sourcebook, 3rd ed.; Sage Publications: Thousand Oaks, CA, USA, 2014.

43. Kurasaki, K.S. Intercoder reliability for validating conclusions drawn from open-ended interview data. Field Methods 2000, 12, 179-194. [CrossRef]

44. Dettinger, M.D.; Sterle, K.; Simpson, K.; Singletary, L.; McCarthy, M.; Fitzgerald, K. Climate Scenarios for the Truckee-Carson River System; University of Nevada Cooperative Extension Special Publication: Reno, NV, USA, 2016.

45. Lang, D.J.; Wiek, A.; Bergmann, M.; Stauffacher, M.; Martens, P.; Moll, P.; Swilling, M.; Thomas, C.J. Transdisciplinary research in sustainability science: Practice, principles, and challenges. Sustain. Sci. 2012, 7, 25-43. [CrossRef]

46. Rosenzweig, B.; Vorosmarty, C.; Gutowski, W.; Steiner, A.L. Joining scientists and stakeholders in regional earth system modeling. Eos Trans. Am. Geophys. Union 2014, 95, 247-248. [CrossRef]

47. Islam, S.; Susskind, L. Understanding the water crisis in Africa and the Middle East: How can science inform policy and practice? Bull. At. Sci. 2015, 71, 39-49. [CrossRef]

48. Bourget, E.C.; Langsdale, S.M.; van den Belt, M. Collaborative modeling for decision support as a tool to implement IWRM. J. Am. Water Resour. Assoc. 2013, 49, 605-608. [CrossRef]

49. Reed, M.S.; Graves, A.; Dandy, N.; Posthumus, H.; Hubacek, K.; Morris, J.; Prell, C.; Quinn, C.H.; Stringer, L.C. Who's in and why? A typology of stakeholder analysis methods for natural resource management. J. Environ. Manag. 2009, 90, 1933-1949. [CrossRef]

50. Voinov, A.; Kolagani, N.; McCall, M.K.; Glynn, P.D.; Kragt, M.E.; Ostermann, F.O.; Pierce, S.A.; Ramu, P. Modelling with stakeholders-Next generation. Environ. Model. Softw. 2016, 77, 196-220. [CrossRef]

(C) 2017 by the authors; licensee MDPI, Basel, Switzerland. This article is an open access article distributed under the terms and conditions of the Creative Commons Attribution (CC BY) license (http:/ / creativecommons.org/licenses/by/4.0/). 